\title{
Who Is The Target Market Of Digital Tourism 4.0?
}

\author{
Author : \\ Felix Goenadhi' dan Dedi Rianto Rahadi ${ }^{2}$ \\ 1Email : felix.goenadhi@president.ac.id \\ 2Email : dedi1968@president.ac.id \\ 12 School of Business President University, Indonesia
}

\begin{abstract}
This study is to investigate the willingness or intention of millennials and Gen Z era because nowadays, they are the new target market and their tourism destination image to visit several places in Indonesia based YouTube accout "Indonesia.Travel" about their promotional video "Wonderful Indonesia-A Visual Journey." In this video, there will be four places. The first one is Bunaken, Manado; Banyuwangi, East Java; Lombok; and Wakatobi. The paper is presenting and experimental research (pre-test and post-test) to measure intention and tourism image of destination places in Indonesia and qualitative method (with Focus Group Discussion) in the open-ended questions. There is a significant influence of post-test to tourism image of choosing a destination in Millenials, and Gen Z and also there is a significantly difference between posttest and pre-test, before and afer the promotional video of "Wonderful Indonesia-A Visual Journey." The Research Limitation/Implication is the subject is only Millenial and Gen Z and this research only use accidental sampling. The practical implication in this research it is hoping that the paper will contribute to making a business about promotional video in other places in Indonesia, or in the world.
\end{abstract}

Keywords: Intention, Destination Image, Promotional Video, Millenials, Gen Z.

\begin{abstract}
Abstrak
Penelitian ini adalah untuk menyelidiki kemauan atau niat era milenium dan Gen $Z$ karena saat ini, mereka adalah target pemasaranyang baru dan gambaran tujuan wisata mereka untuk mengunjungi beberapa tempat di Indonesia berdasarkan video promosi di kanal YouTube "Indonesia.Travel" berjudul "Wonderful Indonesia-A Visual Journey." Video ini terdiri dari 4 tempat yang pertama adalah Bunaken, Manado; Banyuwangi, Jawa Timur; Lombok; dan Wakatobi. Penelitian ini mempresentasikan dari penelitian eksperimental (pre-test dan post-test) untuk mengukur niat dan citra pariwisata dari tempat-tempat tujuan di Indonesia dan metode kualitatif (dengan Diskusi Kelompok Fokus) dalam pertanyaan-pertanyaan terbuka. Penelitian ini menguji citra pariwisata dalam memilih tujuan di Millenials, dan Gen $Z$ dan ditemukan juga terdapat perbedaan yang signifikan antara post-test dan pre-test, sebelum dan sesudah video promosi "Wonderful Indonesia-A Visual Journey." Batasan Penelitian / Implikasinya adalah subjeknya hanya Millenial dan Gen Z, dan penelitian ini hanya menggunakan accidental sampling dalam pengambilan sampling. Implikasi praktis dalam penelitian ini Diharapkan bahwa penelitian ini akan berkontribusi untuk membuat bisnis mengenai video promosi di tempat lain di Indonesia, atau bahkan di dunia.
\end{abstract}

Kata kunci: Niat Berwisata, Citra Pariwisata, Video Promosi, Milenial, Gen Z. 


\section{A. INTRODUCTION}

Developing country and its tourism are facing many obstacles. The example of the obstacle is crime or safety, political unrest, natural disasters, and some places is not aware of hygiene, this is some example of destination image in developing countries. However, tourist destination in developing countries has a nature view, uniqueness cultural, and have a potential to be a market trend, because few international tourist visiting developing country (Avraham \& Ketter., 2016).

In contrary, in Indonesia, international travelers are increasing from 2015 to 2019. Indonesia's Visitor Arrivals recorded 1,483,792 people in Jul 2019, compared with $1,454,141$ people in the previous month. Indonesia's Visitor Arrivals data is updated monthly, available from Jan 1979 to Jul 2019. The data reached an all-time high of 1,547,231 people in Jul 2018 and a record low of 36,730 people in Jan 1979, as showed in the diagram below (CEIC Data, 2019).

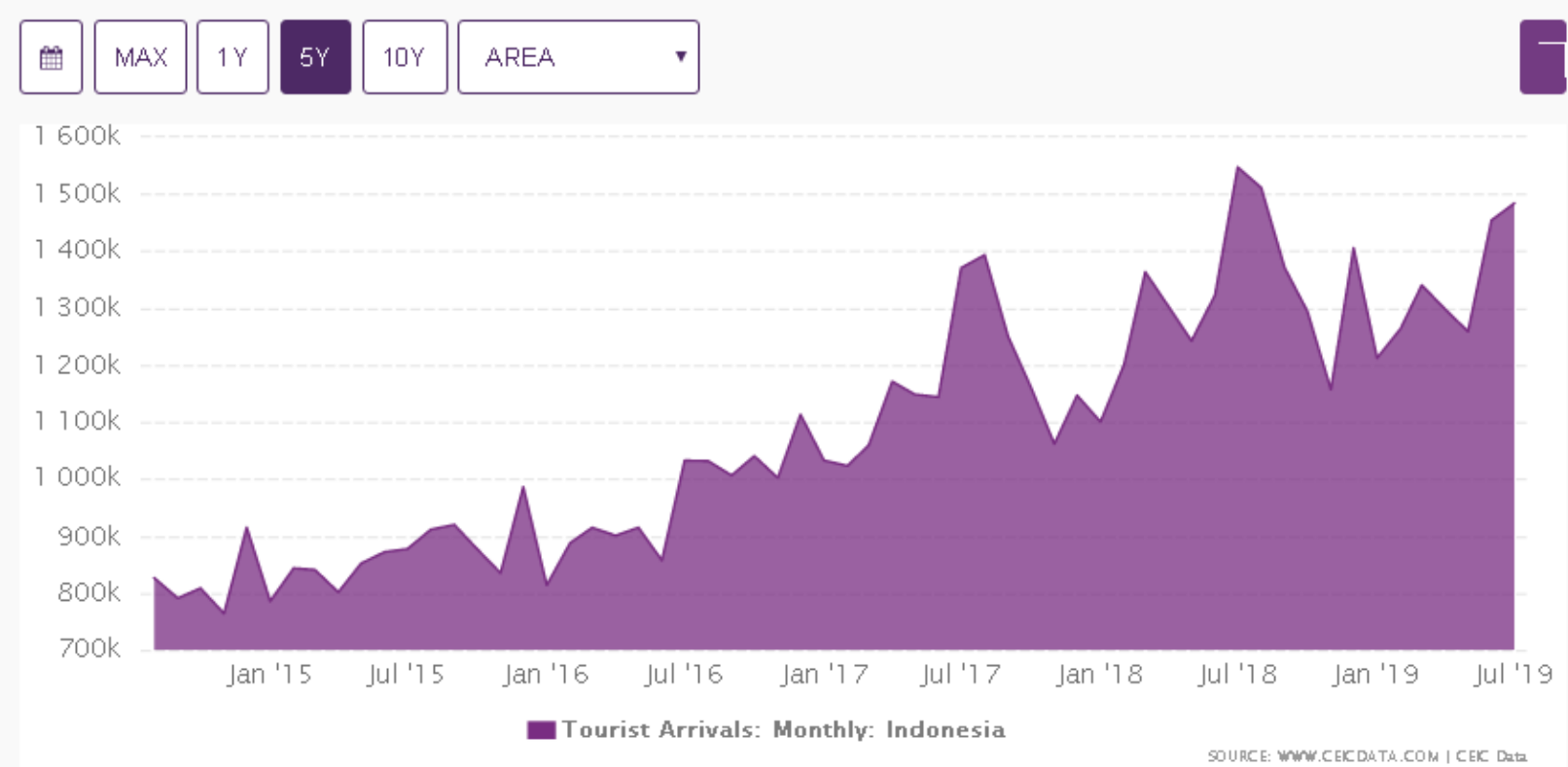

(source: https://www.ceicdata.com/en/indicator/indonesia/visitor-arrivals)

According to the graph above, it is not a secret that Indonesia Minister of Tourism, Dr. Ir. Arief Yahya, M. Sc (2017), said: "tourism is an easiest and cheapest contribution to GDP, Foreign Exchange Earning and Employment." The impact of tourism gave ten percent of national GDP, growth above the average of all industry in Indonesia, also spending USD 1 million. At Foreign Exchange, Indonesia ranked 4th of national foreign exchange, amounted o 9,3 percent, the highest growth, which is 13 percent, and marketing cost only 2 percent of projected foreign exchange. Employment in the tourism industry contributes 9.8 million jobs, new employee grew 30 percent in 5 years, and availability jobs up to 5000 USD per one job.

President of Indonesia, Ir. Joko Widodo, also gave his support to Indonesian tourism which would spend 4 or 5 times for promotional budgeted and branding "Wonderful Indonesia" to attract international tourist in many countries. That will give the impact of 
many international tourists will visit Indonesia. The president also targeted 20 million international tourists that will come to Indonesia until 2019. One of the brandings is the promotional video about "Wonderful Indonesia-A Visual Journey" (Yahya, 2017).

Minister of Indonesian Tourism had a seminar about tourism in Indonesia, and it said about Tourism 4.0, which is in tourism in Indonesia, the target market will be Millenials and Gen $Z$ because they use marketing 4.0 and industry 4.0 is very suitable from them (Hakim, 2018).YouTube is excellent advertising for Millenials and Gen $Z$ because the result of Chang and Fong (2019), compared to Facebook and Web Blog, YouTube gets the highest point (100), Web Blog comes in second with 86, and Facebook gets 70 points.

There are a lof of reaction video of promotional video "Wonderful Indonesia-A Visual Journey" in YouTube. Based on Widiastuti \& Nurtaanzila (2018), we able to know that foreign citizens feel impressed by the beauty of Indonesia. The reaction video can from the description written in each video. BigLezTV wrote the description "Beautiful place that my wife and I must add to our bucket list. This is my reaction to its beauty ... "and The Crabtree Life wrote,"... We learned this place in Indonesia is so beautiful! It is paradise! ..." The impression obtained by the viewers of the video is the result of processing Indonesian promotional materials, which are not owned by other countries (product competitiveness). Ease of foreign citizens to understand the message conveyed in the video on the Indonesian Youtube channel. Travel is not only because of the attractive picture, copy and back sound quality, but also the support of the use of foreign languages in most tourism promotion videos on this channel. Of the 218 videos, 171 English videos (78.44\%), 34 Indonesian videos (15.59\%), 10 Japanese videos $(4.59 \%), 1$ Chinese video $(0.46 \%), 1$ Korean videos $(0.46 \%)$, and 1 Dutch video $(0.46 \%)$. Based on this percentage, we can find out that the target audience of "Indonesia.Travel" channel is foreign citizens. The use of foreign languages in promotional videos is the right choice to introduce Indonesia globally. Promotional material on this YouTube channel is very diverse, ranging from natural wealth, cultural diversity, profiles of tourist destinations, travel vlogs, tour packages, and tourist activities.

Tourism 4.0 is using YouTube as one of the marketing tools, Minister Tourism of Indonesia, upload the promotional video "Wonderful Indonesia-A Visual Journey" in 2017, and it has around a million viewers, however, is that true that video promotional about tourism in Indonesia, going to change the perception of tourism image, and perhaps also giving more intention to visit of the tourism destination in millenials and Gen Z?

\section{B. LITERATURE REVIEW.}

\section{Intention And Tourist Image Of Promotional Video}

There was research about the intention and tourism image that affect the chosen video (Suciati, Maulidyanti, \& Lusia, 2017). Willingness or intention of visiting new places based on their wants, plans, and needs. The promotional videos will drive tourist in their evaluation belief, social factors, and situational beliefs (Ajzen, 2006; Moutinho, 1987). 
According to Ferdinand (2006) in Astuti \& Putri (2018), in watching a video on social media, such as Instagram, YouTube, there is four intention, the first one is Transactional intention, which is one's tendency to purchase a product or willing to spend money to visit the place. Second is Reference intention, which is one's tendency to make a reference of the product to others. Next is Preference intention, which describes the behaviors of a person who has the primary preference for a tourism destination. This preference will only change if something happens to his or her preferred product. Moreover, the last one is Explorative intention, which describes the behavior of a person who always finds information regarding the product he or she is interested in to support the positive features of that destination place.

The transactional intention is related with advertising because it contains levels of marketing, such as receiving the message, processing, communication effect, brand positioning, target customers action, sales or market share, brand quality, and profit generation. Usually travel intention is use by transactional intention; however, in past studies, traveller intention may be an internal and external factor. Internal factor such as preference and explorative intention, external factor intention consist of reference and transactional intention (Chang \& Fong, 2019).

The intention also related with the expectation or destination image based on the promotional video, according to the research of Gudlaugsson \& Magnu'sson (2010), there are 5 destination image based on the result of survey, they are nature and scenery; activities; culture and people; atmosphere and mood; and unique. This significant five criteria will also be added in the research to see in destination image after watching the promotional video and influence of intention to visit. Widiastuti \& Nurtaanzila (2018), there are five categories of destination image in the promotional video "Wonderful Indonesia - A Visual Journey", they are beautiful nature, culture, the hospitality of local people, uniqueness of local food, and peaceful or security of destination places. Destination image consists of cognitive, affective, and conative. Cognitive destiantion image is a beliefs concerning a destination has the ability to influence travel intention during the evaluation of the early consideration set of the decision-making process (Chaulagain, Wiitala, \& Fu., 2019).

Much prior research about destination image and intention said that destination image is related to intention to travel. However, there is a gap of most the research, because the intention item questionnaire is want to visit the place, or intend to visit, not the dimension of purchase intention to travel.

The similar research about pre-test and post-test is from Darmawan \& Sanawiri (2018), said that there was a significant difference between pre-test and post-test after the video of "Wonderful Indonesia- A Visual Journey through Banyuwangi", the indicators are nature, hospitality, culture, and perceived value, and in the indicator said there was a significant difference in that four indicators. However, in this promotional video, the subject of research is not mentioned, such as age, sex, nationality, and it usually called socio-demographic. In their research also have a limitation in a variable, for example, intention or willingness tourist, and tourist destination image just at Banyuwangi, East Java. Darmawan \& Sanawiri said in the research that need improvement such as 
destination place not just in Banyuwangi. Promotional video as a media of tourism is an essential, because media is a first gate to growth of a destination place (Hakim, 2018).

Reino \& Hay (2016) in their research said that the tourist still unaware about promotional video, usually the audience saw advertising in the video that they choose, not intentionally see the promotional video of the tourism destination. It also said that YouTube need to develop the role of YouTube in the marketing of tourism. However, Huertas, et al. (2016), the research showed that audience of YouTube more using search engine in apps or web based 2.0, specialy when they want to travel and potential traveler gain information in comment section. It is similar outcome with Marine-Roig (2017), that potential traveler using search engine in social media to find a tourist destination, however, the limitation in that research it is contain about information technology, algorithm, not about tourism image, identity, authenticity, sustainability, or smartness of tourist destinations.

"Indonesia.Travel" is an account of tourism marketing under Indonesia minister of toursim in YouTube, there are 5 top promotional videos according to viewers, the first one is the promotional video with title "Wonderful Indonesia - A Visual Journey" has more than 2 million viewers, second is "Wonderful Indonesia- A Visual Journey through Banyuwangi", has around 145 thousand viewers, followed by "Wonderful Indonesia- A Visual Journey through Bunaken" has around 130 thousand viewers, next is promotional video "Wonderful Indonesia- A Visual Journey through Lombok" has around 180 thousand viewers, the last one is "Wonderful Indonesia- A Visual Journey through Wakatobi" has around 18 thousand viewers. In the promotional video with title "Wonderful Indonesia - A Visual Journey", there are lof numbers in video reaction, and most of the video reaction is amazed about nature, culture, sea, beach, and underwater activities. The reaction video will increase the popularity of original video (Kavoura, et al., 2019). In the promotional video, it contains nature, landscape, arts, and adventure (Claristy, 2016).

The purpose of this research is to see the intention to visit from millennials and Gen Z, tourism images in tourism destination in Indonesia based on the promotional video.

\section{RESEARCH METHOD}

The method of this research is using True- Experimental Design with The One Group Pre-test and Post-test. The purpose of this research is to determine two sample comparisons of the experimental design carried out in one group without a comparison group. This research also to figure the influence about intention from post-test and destination image according to promotional videos.

The audience will give a questioner before watching promotional video, and survey administrator will collect the pre-test, and after that the audience will watch 5 videos, first is "Wonderful Indonesia- A Visual Journey through Banyuwangi", followed by "Wonderful Indonesia- A Visual Journey through Bunaken", next is promotional video "Wonderful Indonesia- A Visual Journey through Lombok", the fourth one is "Wonderful Indonesia- A Visual Journey through Wakatobi", and the last one is "Wonderful 
Indonesia-A Visual Journey". After finish watching all the promotional five videos, the audience will fill a questioner will add on closed questions about the place to visit.

The closed questions will be measure in Likert scale from 1 (Strongly Disagree) to 5 (Strongly Agree), and the statement in the questionnaire are;

1. I will pay sum of money to visit destination tourism in Indonesia.

2. I will go with my friends or family to visit destination tourism in Indonesia.

3. I will invite my friend or family to visit destination tourism in Indonesia.

4. Visiting destination tourism in Indonesia will be my first priority on vacation.

5. I will search for information about tourism destination in Indonesia.

6. I support positively from tourism destination in Indonesia.

7. I will travel to visiting one of destination in Indonesia above.

The add on in quesionare after the video for tourst image will be a box to tick using Likert scale from 1 (Not Very Interesting) to 5 (Very Interesting), and the box will be;

I will go there because: (In Order, 1 Very Not Interesting, 5 Very Interesting)

\begin{tabular}{|l|l|l|l|l|l|}
\hline & 1 & 2 & 3 & 4 & 5 \\
\hline $\begin{array}{l}\text { Nature or } \\
\text { Scenery }\end{array}$ & & & & & \\
\hline Activities & & & & & \\
\hline Culture or people & & & & & \\
\hline $\begin{array}{l}\text { Atmosphere or } \\
\text { mood }\end{array}$ & & & & & \\
\hline Unique & & & & & \\
\hline
\end{tabular}

(adaption from Gudlaugsson\&Magnu'sson, 2010)

And a tick box to pick one of tourism destionation, the question will be;

Destination tourism in Indonesia you want to visit:

$\square$ Banyuwangi, East Java $\square \quad$ Bunaken, North Sulawesi

$\square$ Wakatobi , Southeast Sula $\square_{\mathrm{i}} \quad$ Lombok, West

Nusa Tenggara

\section{Survey Implementation}

The subject of this research is Millenial and Gen Z, because of they familiar with social media such as YouTube and Instagram (Suciati, Maulidiyanti, \& Lusia, 2017).

The survey using a structured measurement and using the Likert Scale and will be selfadministered. The survey administrator stood in front of millennials and Gen $Z$ while they were doing the self-administered survey. After that, the survey administrator will give a link to the video on YouTube, and maybe the survey administrator will look together with the group of participant. The media that survey administrator is using it can be a mobile phone or laptop, depends or the situation. After that survey 
administrator will give the second questioner for them to fill it up, and get the paperback. In that group, as well as survey administration, will ask several questions:

1. What is the most interesting in that video, and why?

2. Would you go there, and why?

It is an open question, so every member of groups should answer it and give their opinion, and survey administrator will write it down the answers.

This research is using a convenience sample to gather 111 people of millennials and Gen $Z$ type, and some of the participants, it is divided into a group of 7 or 8 . Collecting data targeted in one month and calculate the quantitative and qualitative data will be the target in one month.

\section{RESULT}

\section{Pre And Post-Test}

Tabel 1. Socio Demography of Participant

\begin{tabular}{|c|c|c|}
\hline Item & Frequency & Precent \\
\hline \multicolumn{3}{|c|}{ Gender } \\
\hline Male & 43 & $38,74 \%$ \\
\hline Female & 68 & $61,26 \%$ \\
\hline Total & 111 & $100 \%$ \\
\hline \multicolumn{3}{|c|}{ Age } \\
\hline$<17$ Years Old & 14 & $12,61 \%$ \\
\hline 18 - 30 Years Old & 91 & $81,98 \%$ \\
\hline > 31 Years Old & 6 & $5,41 \%$ \\
\hline Total & 111 & $100 \%$ \\
\hline \multicolumn{3}{|c|}{ Nationality } \\
\hline Indonesian & 70 & $63,06 \%$ \\
\hline Non Indonesian & 41 & $36,94 \%$ \\
\hline Total & 111 & $100 \%$ \\
\hline \multicolumn{3}{|c|}{ Destination to Visit } \\
\hline $\begin{array}{l}\text { Banyuwangi, East Java } \\
\text { Wakatobi, Southeast }\end{array}$ & 9 & $8,11 \%$ \\
\hline Sulawesi & 18 & $16,22 \%$ \\
\hline $\begin{array}{l}\text { Bunaken, North Sulawesi } \\
\text { Lombok, West Nusa }\end{array}$ & 30 & $27,03 \%$ \\
\hline Tenggara & 54 & $48,65 \%$ \\
\hline Total & 111 & $100 \%$ \\
\hline
\end{tabular}

Source: computing from SPSS ver. 20

The domination of this research is female $(61,26 \%)$, male $(38,74 \%)$; age is below 17 years old is $12,61 \%, 18-30$ years old is $81,98 \%$, above 31 years old is 5,41 . 
Nationality in this research is dominating by Indonesian (63,06\%) and Non-Indonesian $(36,94 \%)$. The top destination in this research is Lombok, West Nusa Tenggara $(48,65 \%)$, Bunaken come in second place $(27,03 \%)$, Wakatobi, Southeast Sulawesi $(16,22 \%)$, and the last one is Banyuwangi, East Java (8,11\%).

Table 2. Compare Mean Rank

\begin{tabular}{|ll|r|r|r|}
\hline & N & $\begin{array}{c}\text { Mean } \\
\text { Rank }\end{array}$ & $\begin{array}{c}\text { Sum of } \\
\text { Ranks }\end{array}$ \\
\hline & $\begin{array}{l}\text { Negative } \\
\text { Ranks }\end{array}$ & $47^{\mathrm{a}}$ & 38,37 & 1803,50 \\
Total Post-Test - & $\begin{array}{l}\text { Positive } \\
\text { Total Pre-Test }\end{array}$ & $51^{\mathrm{b}}$ & 59,75 & 3047,50 \\
& Ranks & $13^{\mathrm{c}}$ & & \\
& Ties & 111 & & \\
\hline
\end{tabular}

a. Total Post-Test < Total Pre-Test

b. Total Post-Test $>$ Total Pre-Test

c. Total Post-Test $=$ Total Pre-Test

From: SPSS ver.20

The result in table 2, there is more positive rank (post-test is higher than pre-test) which is 51 participants, and negative rank (post-test is lower than pre-test), which is 47 participants, and ties (pre-test is equal to post-test) s 13 participants.

Table 3. Asymp. Sig

\begin{tabular}{|l|r|}
\hline & $\begin{array}{r}\text { Total Post- } \\
\text { Test - Total } \\
\text { Pre-Test }\end{array}$ \\
\hline $\begin{array}{l}\text { Asymp. Sig. (2- } \\
\text { tailed) }\end{array}$ & $-2,209 \mathrm{~b}$ \\
&, 027 \\
\hline
\end{tabular}

a. Wilcoxon Signed Ranks Test

b. Based on negative ranks.

Source: SPSS ver. 20

According to Table 3 , there is a significanly difference between post-test and pre-test, where 0,027 is below 0,05 , so the hypotesis that acceptabel is $\mathrm{H} 1$, there is difference significanly between post-test and pre-test.

\section{Regression Analysis}

The result of tourism image of potential tourist, the researcher using regresion from SPSS, and the table in table 4 below. 
Table 4. Regression Model

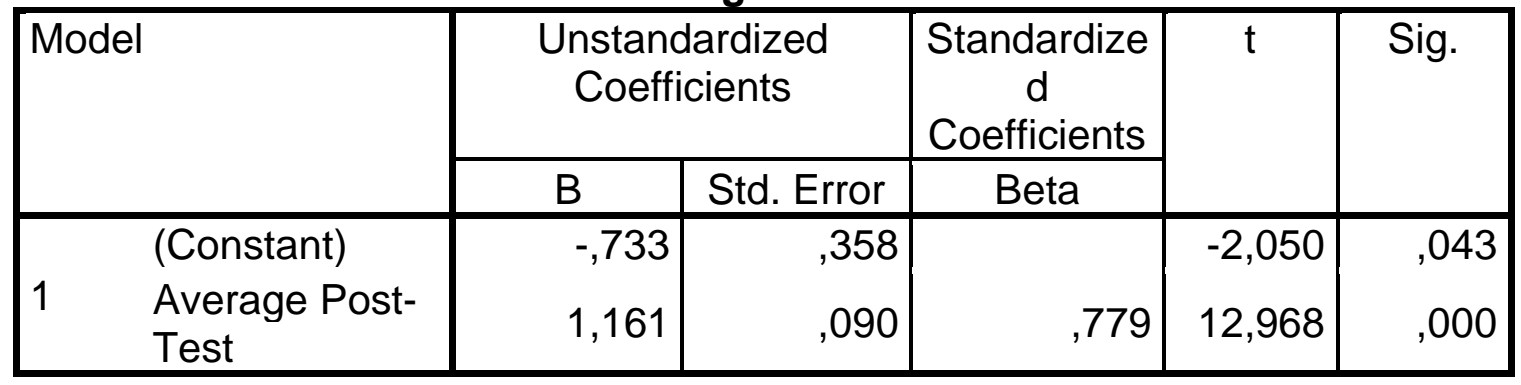

a. Dependent Variable: Average Choosing From: SPSS Ver.20

From table 4, there is a significant influence of post-test to tourism image of choosing a destination, because the minimum is below 0,005, and it gets 0,000. In regression equation $Y=a+b X$, in $Y$ is a Tourism Image, $a$ is a constant, $b$ is Beta for $x$ variables (Intention to visiting), it is get $Y=(-0,733)+1,161 X$. There is a positive influence significant because of the intention. However, the tourism image itself has had a negative result $(-0,733)$, in other words, tourism image in tourism destinations places is bad or had a negative number, however, because of the promotional video the number is 1,161 giving a good influence to make tourism image good.

Table 5. R Square

\begin{tabular}{|l|c|r|r|c|}
\hline $\begin{array}{l}\text { Mode } \\
l\end{array}$ & $R$ & $\begin{array}{c}\mathrm{R} \\
\text { Square }\end{array}$ & $\begin{array}{l}\text { Adjusted R } \\
\text { Square }\end{array}$ & $\begin{array}{c}\text { Std. Error of } \\
\text { the } \\
\text { Estimate }\end{array}$ \\
\hline 1 &, $779^{\mathrm{a}}$ &, 607 &, 603 &, 59487 \\
\hline
\end{tabular}

a. Predictors: (Constant), Average Post-Test

Source: SPSS ver. 20

In table 5 the $\mathrm{R}$ Square or Correlation between questionnaire from intention to visiting and destination image from video promotional get the result 0,607 , it is indicate that $60,7 \%$ intention to visiting is to generate from video promotional, and $29,3 \%$ is from other variables.

\section{Mean Destination Image}

Table 6. Mean of Destination Image

\begin{tabular}{|l|l|}
\hline Item of Destination Image & Mean \\
\hline Nature or Scenery & 4,12 \\
\hline Activities & 3,53 \\
\hline Culture or people & 3,71 \\
\hline Atmosphere or mood & 4,03 \\
\hline Unique & 3,94 \\
\hline
\end{tabular}

Source: Research computing, 2019 
Based on table 6 , destiantion image from potential traveler, nature or scenery with 4,12 , activities get mean 3,43 , culture or people get mean score of 3,71 . Atmosphere or mood get 4,03 , and unique get 3,94

\section{E. DISCUSSION}

According to the result, there are significant differences because the promotional video and intention of potential traveller are on YouTube. In YouTube itself, there is a reaction video about a promotional video of Wonderful Indonesia-A Visual Journey, and most are their reaction amazed, cried, exciting and joyful. In Focus Group Discussion with some of the millennials and Gen Z, they also said, that it captures the enjoyment of the promotional video. This result is similar with research from Huertas (2016), that the audience find out about felling exciting and sincerity to target potential tourist in Spain.

In pre-test and post-test in this research, getting a result is there is a significant difference. In post-test there an increase willingness to visit the Indonesia Tourism places. It is similar with research result from Widiastuti \& Nurtaanzila (2018), said that promotional video about destination in Indonesia is giving a willingness to travel to Indonesia.

The majority tourism destination they want to visit is in Lombok, West Nusa Tenggara, because in this video it is consist all five aspects from beautiful nature, culture, the hospitality of local people, uniqueness of local food, and peaceful or security of destination places.

If there is no promotional video, the destination image is not doing well or get negative impact, but after promotional video, the destination image is higher. The most destiantion image in this research is Nature or Scenery, follow by Atmosphere or mood, third is Unique, fourth is Culture or people, and the last is Activities. It is related to Focus Group Discussion, because many participants in Focus Group Discussion said that "I just know it, that Indonesia has that beautiful places", both in Indonesian and NonIndonesian.

In Focus Group Discussion, most of the participant said, that safety is the main reason among that tourist destination in Indonesia. However, the intention after watching the tourism destination video, most of the participant of Focus Group Discussion said, that they are enjoying the video, and want to travel to the places. Most unusual in that video was the subjective view of the mountain, and some said that culture, kids interaction, and the sea itself.

\section{LIMITATION AND FURTHER RESEARCH}

Convenience sample selected is not generalized the whole population. However, the result of this paper is to give an excellent promotional video that effect intention and tourism image that drives potential tourist to visit that destination in the video.

Millennials and Gen $Z$ also a downside because of the financial issues, they do not have much money to spend in tourism place but has more time to spend in the destination 
places. The result, however, showed that they have a willingness to spend their money to visiting there.

In further research, it will be a great benefit with another promotional video from other tourist destination or other Destination Management Organization, and perhaps changing the participant age group to find out the difference between the group age. Safety, hygiene, and political issues may used as a intention for motivation to visiting tourism destination in developing country.

\section{F. CONCLUSION}

In conclusion, the promotional video has made a significant contribution to changing the intention of visiting a tourist destination in Indonesia. In pre-test, the result was low, but after the promotional video has shown, the intention is increasing and has a significant difference. In other words, the promotional video is doing its job very well. Intention and destination image have a significant influence.

According to result in this research, destination tourism promotional video gives a significant impact to influence potential traveller, so there is a business for concent creator, especially in video making about the promotional video in a tourist destination in Indonesia tourism.

\section{REFFERENCE}

A. Kavoura et al. (eds.), Strategic Innovative Marketing and Tourism. Springer Proceedings in Business and Economics, seen at https://doi.org/10.1007/978-3030-12453-3_101.

Astuti, B., \& Putri, A. P. (2018). Analysis on the Effect of Instagram Use on Consumer Purchase Intensity. Review of Integrative Business and Economics Research, Vol. 7, Supplementary Issue 2.

Avraham, E., \& Ketter, E. (2016). Introduction: Tourism Marketing for Developing Countries. Tourism Marketing for Developing Countries, 1-7. doi:10.1057/9781137342157_1

CEIC Data. (2019). Indonesian Visitor Arrivals. Seen at https://www.ceicdata.com/en/indicator/indonesia/visitor-arrivals.

Chang, H. H. \& Fong, T. Y. A. (2019). The advertisements effects on festival and destination marketing: comparison study between old and new social media. Travel and Tourism Research Association: Advancing Tourism Research Globally.

Chaulagain, S., Wiitala, J., \& Fu, X. (2019). The impact of country image and destination image on US tourists' travel intention. Journal of Destination Marketing \& Management, 12, 1-11. doi:10.1016/j.jdmm.2019.01.005 
Clarisity. (2016). Kampanye "Wonderful Indonesia" Sebagai Nation Branding Indonesia (Optimalisasi Terhadap Media Kampanye Yang Digunakan). UIANA.

Darmawan, E. W., \& Sanawiri, B. (2018). Dampak Video Promosi Wonderful Indonesia A Visual Journey Through Banyuwangi Terhadap Perubahan Persepsi Citra Destinasi Banyuwangi.JurnalAdministrasiBisnis (JAB)|Vol. 62 No. 2 September 2018.

Gudlaugsson, T.\&Magnu'sson, G (2010).North Atlantic Island Destination in Toursts' Minds. International Journal of Culture, Toursim and Hospitality Research, Vol. 6, No. 2. 2012, pp. 114-123. ISSN 1750-6182 DOI 10.1108/17506181211233045.

Hakim, I. N. (2018). "Pergeseran Budaya Siber \& Visual di Sektor Pariwisata Indonesia" Respon Kementerian Pariwisata Menghadapi era Tourism 4.0 Melalui Peran Komunitas Milenial \& Pengembangan Destinasi Digital. Seminar Nasional Seni dan Budaya "Konvergensi Keilmuan Seni Rupa dan Desain Era 4.0" FBS Unesa, 25 Oktober 2018

Huertas, A., et al. (2016). YouTube usage by Spanish tourist destinations as a tool to communicate their identities and brands. Journal of Brand Management. Macmillan Publishers Ltd. 1350-231X

Marine-Roig, E. (2017). Measuring Destination Image through Travel Reviews in Search Engines. Sustainability, 9(8), 1425. doi:10.3390/su9081425

Reino, S. \& Hay, B. (2016). The Use of YouTube as a Tourism Marketing Tool.Travel and Tourism Research Association:Advancing Tourism Research Globally. 69. See at https://scholarworks.umass.edu/ttra/2011/Visual/69 (16 September 2019).

Suciati, P., Maulidiyanti, M., \& Lusia., A. (2017). Cultivication Effect of Tourism TV Program and Influencer Instagram Account to The Intention of Traveling. The $1^{\text {st }}$ International Proceeding Conference on Social Science.

Widiastuti, R. \& Nurtaanzila, L. (2018). Membaca Citra Indonesia Dalam Arsip Audio Visual Kementerian Pariwisata. Jurnal Diplomatika Vol. 2, pp: 44 - 53.

Yahya, A. (2017). Wonderful Indonesia: Tourism Development Investment Oppurtunities. Indonesia Australia Business week, Jakarta: $7^{\text {th }}$ March 2017. 